\title{
Orthodontic and pediatric dental treatment approach in patient with multiple dental anomalies
}

\author{
Abordagem ortodôntica e odontopediátrica em paciente com múltiplas anomalias dentárias
}

Ricardo Alves SOUZA ${ }^{1}$

Alberic Costa CARVALHO'

Larissa Passos BARRETTO'

Francisco Xavier Paranhos Coêlho SIMÕES'

\begin{abstract}
The purpose of this clinical case report is to discuss the approach to oral rehabilitation of a patient with severe dental alterations such as enamel hypoplasia, change in shape, supernumerary tooth, dental ankylosis, agnesia and crowing in the incisor region. All of these problems compromised not only the esthetical and functional aspects of this patient, but his social relationships as well. Thus integrated planning between Pediatric Dentistry and Orthodontics made it possible to provide the best treatment alternative to recover the patient's stomatognathic system. Esthetic restorations were performed in the anterior tooth region with the use of resin composites, in addition to the use of removable orthodontic appliances, associated with serial extractions and supernumerary tooth removal. There were significant improvements in the esthetic and functional aspects of dentition, in addition to the patient demonstrating good evolution in his psychosocial condition, as he smiled and was more communicative during each follow-up appointment, also according to his mother's reports.
\end{abstract}

Indexing terms: Orthodontic. Pediatric dentistry. Tooth abnormalities.

\section{RESUMO}

Este relato de caso clínico tem o intuito de abordar a reabilitação oral de um paciente que possuía alterações dentárias severas, como hipoplasia de esmalte, alteração de forma, dente supranumerário, anquilose dentária, agenesia, e apinhamentos na região de incisivos. Todos estes problemas comprometiam além do aspecto estético e funcional, as relações sociais deste paciente. Desta forma um planejamento integrado entre Odontopediatria e Ortodontia possibilitou a melhor alternativa de tratamento para recuperar o sistema estomatognático do paciente. Foram realizadas restaurações estéticas na região de dentes anteriores com o uso de resinas compostas, além da utilização de aparelhos ortodônticos removíveis, em associação com extrações seriadas e remoção de dente supranumerário. As melhorias no aspecto estético e funcional da dentição foram bastante expressivas, além disso, o paciente demonstrou uma boa evolução no quadro psicossocial, pois o mesmo apresentava-se sorridente e mais comunicativo durante cada consulta de acompanhamento, e segundo relatos da própria mãe.

Termos de indexação: Ortodontia. Odontopediatria. Anormalidade dentária.

\section{INTRODUCTION}

In the period corresponding to mixed dentition, great alterations occur in the dental arches, and consequently, some deviations from normality may occur in this stage of the child's intense growth. Therefore, the interaction between the specialties of Pediatric Dentistry and Orthodontics makes it possible to correct these morphological and functional changes resulting from diverse ecological factors, in a more dynamic manner, capable of being controlled by the professional ${ }^{1-2}$.
In this dynamic process of development, changes such as enamel hypoplasia, supernumerary teeth, agnesia, crowding, anomalites of shape and position may occur and generate much damage to the health of the pediatric dental patient. Furthermore, psychosocial problems related to compromise of dentofacial esthetics, changes in mastication and swallowing may also occur, among others related to trauma, periodontal disease and caries ${ }^{3}$. The presence of various disturbances in oral health in the same patient in childhood may result not only in difficulty in performing conventional treatment, but also in psychological

\footnotetext{
${ }^{1}$ Universidade Estadual do Sudoeste da Bahia, Faculdade de Odontologia. Av. José Moreira Sobrinho, s/n., Jequiezinho, 45200-000, Jequié, BA, Brasil. Correspondência para / Correspondence to: RA SOUZA. E-mail: <ricardoorto@gmail.com>
} 
implications, because the child is at the stage of development of his/her affective and social relationships ${ }^{4}$.

It is important to point out that dental anomalies result from deviations from the normal process of growth, development and cell differentiation. They occur due to environmental and genetic factors, or as manifestations of systemic disturbances. Around $10 \%$ of the congenital malformations are of a hereditary nature, another $10 \%$ are considered as arising from a pathological environment, and $80 \%$ are of unknown or not demonstrated etiology 5 .

The importance of the study of these anomalies in Pediatric Dentistry resides in the fact that by means of early diagnosis, one may prevent the onset of occlusal problems, not only in primary and mixed, but also in permanent dentition. Although many of these conditions may be detected in radiographs while the child is still in the stage of primary or mixed dentition, little attention has be related to the investigation of these alterations in patients during early childhood. Therefore, the need for further studies is observed, in order to contribute to the diagnosis and treatment of these abnormalities ${ }^{6-7}$.

In this sense, a multidisciplinary approach is most relevant, because it shows the repercussion of esthetic and functional treatments in a practical manner, as well as in the patient's self-esteem. Therefore, the aim of this study was, by means of a clinical case report, to present the oral rehabilitation of a child patient with various severe dental alterations, with an approach to functional, esthetic and psychosocial factors.

\section{CLINICAL CASE}

The patient, a 10-year-old boy, sought dental treatment ad the Dental Module of the State University of Southeast Bahia, where his mother reported that the child's teeth did not grow in the correct manner. During the first appointment, it was observed that the patient presented a risk identified with dental caries due to the presence of some active lesions.

When analyzing the mother's report, it was found that when the child was around one year of age, he fell from his mother's lap, and consequently there was extrusion of some teeth and dilaceration of the gingiva. Afterwards, the patient suffered another trauma in the facial region in which intrustion of a mandibular incisor occurred, and when he was eight year old; he had a bicycle accident and traumatized the chin region.

On physical extraoral exam, a mesiofacial pattern was shown, absence of passive lip sealing, convex profile, and smile with accentuated tooth asymmetry due to the patient's malocclusion. The patient also presented enamel hypoplasia lesions in the maxillary teeth, tooth 22 with change in shape and in palatoversion, supernumerary tooth in the region of tooth 13, agnesia of tooth 35, crowding of mandibular teeth and tooth 11, causing both esthetic and functional harm. In addition, the mother's report about the child's difficulties in habitual social relationships with children of that age was incisive, because the patient did not smile in public, and was extremely shy at home and at school (Figures 1 and 2).

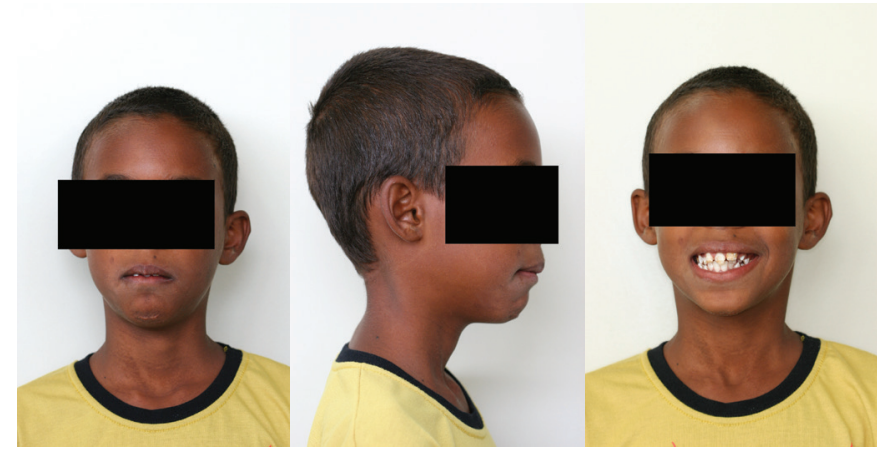

Figure 1. Initial aspect of case, extraoral photographs.
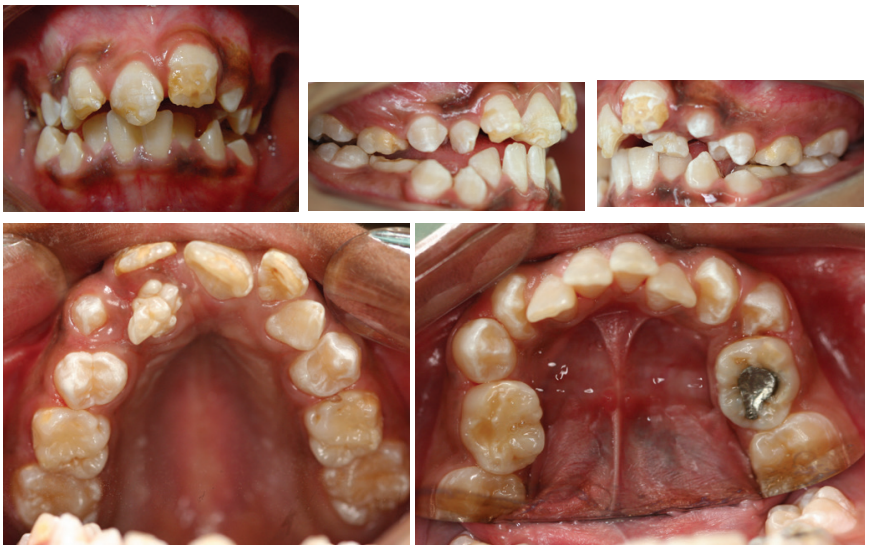

Figure 2. Initial aspect of case, intraoral photographs.

After general evaluation of the patient, joint planning between Incerceptive Orthodontics and Pediatric Dentistry was prepared. Initially, esthetic restorations were performed in teeth 12, 11, 21 and 23, using Opallis resin composite for dentin and enamel (FGM, Joinville, Brasil), in the following sequence of procedures: anesthesia and prophylaxis of the tooth with rubber cap, pumice stone and water, absolute isolation of the operative field, performed with extreme difficulty due to the present of the supernumerary tooth and extrusion of tooth 21. For enamel surface wear, diamond tips 1514 (KG Sorensen, 
Cotia, Brasil) were used, and immediately afterwards, hybridization was performed by association of the $37 \%$ phosphoric acid etching technique for 15 seconds, and abundant washing with air/water spray for the same time. After cavity drying with a jet of air, leaving the etched margins with a whitened aspect, a primer/adhesive system (Prime Bond, Dentsply, Petropolis, Brasil) was applied with a microbrush on the entire surface. With a light jet of air the solvent was evaporated, followed by light polymerization for 20 seconds. The restoration was performed by the incremental tecnhique, using resin composite in approximately $2 \mathrm{~mm}$ thick increments, followed by light polymerization of each portion for 20 seconds. On conclusion, the restoration was finished and polished with multi-bladed burs and special points for resin composite finishing (Figure 3).
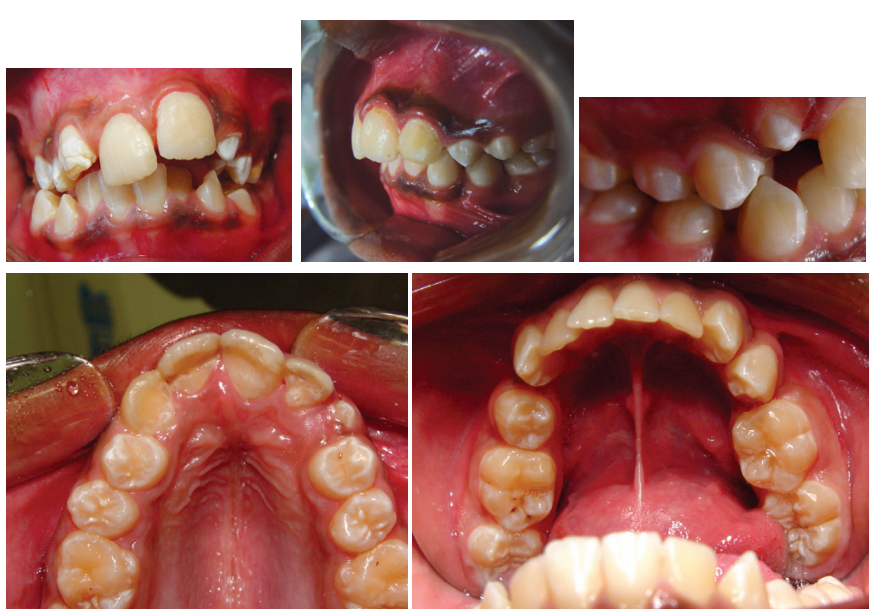

Figure 3. Final aspect of the case.

For space management, teeth $22,44,54,74$, and supernumerary tooth in the region corresponding to tooth 13 were extracted, in addition to Interceptive Orthodontic resources in order to minimize the patient's severe tooth crowding and reduce the damage. The parents were aware of the orthodontic limitations of a treatment performed in an undergraduate dental clinic.

After impression-taking of the work, removable orthodontic appliances were fabricated. In the maxillary arch, the appliance had two Adams type retention clips, two interproximal, and one of a Hawley type arch fabricated with $0.7 \mathrm{~mm}$ orthodontic wire. For the mandibular arch, two Adams type retention clips, a modified Hawley arch with digital lingual springs, and a modified $\mathrm{C}$ clip with a digital spring in the region of tooth 44 . The spaces obtained with the extractions were administered by means of wear of the acrylic appliance that functioned as a space retainer.
The patient was motivated and instructed to use the appliance 24 hours a day, and remove it only during means, for cleaning and oral hygiene. The mother was instructed about the weekly maintenance of the appliances and the possible repairs to the restorations until the maximum esthetic and occlusal corrections had been obtained.

The treatment presented a satisfactory result, because by professional evaluation, it was possible to observe significant improvement in the patient's occlusion after the removal and repositioning of some of the tooth units. Furthermore, an evolution was observed with regard to the crowding, provided by the serial extractions and removable orthodontic appliances, in addition to the natural extrusion of the central incisor that had presented in infraversion. The esthetic condition became more favorable by the resin composite restorations, a fact proved by the patient's satisfaction with his smile and considerable improvement in social contact, according to the report by the child's mother (Figure 3).

This clinical case was submitted to and approved by the Research Ethics Committee of the State University of Southeast Bahia, Protocol No. 013/2009, thereby complying with the ethical principles contained in the Helsinki Declaration (2000). It is worth mentioning that the person responsible for the patient signed the Term of Free and Informed Consent, agreeing to the necessary treatment and disclosure thereof.

\section{DISCUSSION}

An integrated approach by Orthodontics and Pediatric Dentistry, during the stages of primary and mixed dentition is extremely important by virtue of the possibility of making an early diagnosis of dental alterations and malocclusions, which allow less complex treatment and a better prognosis ${ }^{8}$.

In the present study, the child presented various dental alterations, such as enamel hypoplasia, change in shape, in palato version, supernumerary tooth, agnesia and crowding. The majority of these disturbances may be related to a series of tramas, reported by the mother, to which the patient was submitted during the stage of primary and mixed dentition ${ }^{9-12}$. Therefore, as traumatism at the stage of primary dentition occurs very frequently, it may be determinant of the alterations in the sequence of permanent successor tooth eruptions, alteration of dental germs in formation, among them enamel hypoplasia, opacity of the crowns, malformation and malpositioning of the teeth ${ }^{12-13}$. 
In a study conducted to evaluate the traumatic effect of injuries in primary dentition which precede permanent dentition, after monitoring a group of children whose ages varied from two to four years, defects were verified in the permanent successors, including opacity of the crowns, hypoplasia, dilaceration, retarded eruption, and alignment. In this study, it was concluded that the injuries in primary dentition definitvely affected the permanent teeth ${ }^{12}$.

Among the anomalies present, the patient in this case presented deep enamel hypoplasia lesions, attaining the amelodentinal junction in the maxillary anterior teeth. For this reason, the option was to perform dental reconstitution by resin composite restoration, because there was less need for dental structure wear, low cost and high possibility of achieving resolution, when compared with other treatment options;

Various studies have evaluated some manners of re-establishing the esthetics of anterior teeth affected by enamel hypoplasia involving only one tooth. The solutions related were the use of total metal ceramic crowns, esthetic porcelain veneers or esthetic restorations with the use of resin composite. The advantage of using resin composite is less need for dental structure wear and treatment performed in only one session. However, it is important to point out that with the associated of materials and adhesive techniques, esthetic cases may be resolved with minimal dental tissue destruction ${ }^{15}$.

In this clinical case, the presence of a supernumerary tooth located in the region of tooth 13 was also diagnosed, which was extracted. According to the literature, once the presence of a supernumerary tooth has been found, whether it has erupted or is impacted, and it is interfering in the establishment of normal occlusion, it should be extracted, provided that it does not harm the root development of the adjacent teeth ${ }^{11}$.

Therefore, the early removal of supernumerary teeth is justified when these are interfering in the eruption or formation of normal adjacent teeth, originating cystic lesions and tumors or erupting ectopically. Thus, the option taken was to extract the tooth, as it was noted that the patient experienced problems in masticatory and phonetic function, there was interference in the eruption of tooth 22 and consequently, an esthetic problem resulting from the presence of this supernumerary tooth ${ }^{11}$.

In addition to these problems, the patient presented a change of shape and palatoversion in tooth 22. The treatment option of extraction was performed, since this tooth caused harm to the patient, such as changes in occlusion and esthetics, consequences that justified the choice of this type of intervention.

Moreover, agnesia of tooth 35 was observed, a condition that many authors consider related to nutritional, traumatic, infections, hereditary or phylogenetic factors. It was an anomaly that not only caused the patient and his parents esthetic concerns, but was also directly related to the development of problems in occlusion?

In his study, Magnusso ${ }^{16}$ found a prevalence of $7.9 \%$ in his sample with hypodontia and malformation of permanent teeth, in which the teeth most commonly absent were the second mandibular premolar and the maxillary lateral incisor. No statistically significant difference was found between the fact that the individual was of the male or female sex and the presence of hypodontia. These findings are in agreement with those reported by Davis ${ }^{17}$ and Stritzel et al. ${ }^{18}$ and corroborate the condition found in the patient of this case.

As reported, the patient presented tooth crowding in the anterior-inferior region, alterations for which treatment could be performed conservatively, with interproximal wear, for example, or tooth extractions and removable orthodontic appliances. The option for one of these methods is directly associated with the severity of malocclusion, the amount of crowding and cooperation from the patient ${ }^{19}$

Therefore, the goal of orthodontic treatment is to achieve satisfactory esthetic and functional results. In the case here reported, the treatment chose was performed according to orthodontic planning, in which the extraction of units 44 and 74 and insertion of removable orthodontic appliances were performed. However, due to the various anomalies present in this patient, the need was observed for continuity of the treatment with a fixed orthodontic appliance. Nevertheless, considering the limitations of clinical tratment at undergraduate level and the socioeconomic conditions of the patient, the planning carried out was the best possible treatment option at the time, and it was evident that there was a significant reduction in the severity of the case.

In agreement with the data surveyed by the Ministry of Health ${ }^{20}$, the prevalence of malocclusions occupies the third highest place in the ranking of oral health problems in Brazilian territory. Therefore, Almeida et al. ${ }^{21}$ have affirmed that malocclusions are pathological entities that interfere in the individual's well-being, with normal occlusion being an imperative factor in health. However, there is still considerable scarcity of preventive orthodontic treatment in the public health service, in 
spite of the significant demand in the population. After conclusion of this clinical case, it was evident that it had not been possible to completely resolve the patient's malocclusion, nevertheless, the esthetic, functional and psychosocial harm could be minimized in such a way that the patient achieved a significant improvement in his general and oral health.

Approaches such as the one proposed in this report, if well conducted in patients at early ages an in the most varied types of malocclusion, may avoid the need for more complex treatment such as Corrective Orthodontic or even Orthognathic Surgery treatment. Moreover, the implementation of Interceptive Orthodontics is perfectly feasible in all the Dental Specialty Centers, as it presents a relatively low operational cost, in order to amplify the oral health programs with preventive and interceptive actions in the public services in the country

With regard to the psychosocial aspect, factors such as the normality of shape, color and position of teeth are important esthetic factors in contemporary social life and in the behavior of the individual. In this sense, a compromised smile may negatively influence the development of the individual's personality with harm to self-confidence and self-esteem. Therefore, individuals with damaged teeth are led into a state of emotional uncertainty, as they tend to feel sad, fearful and worried, causing a negative impact on their quality of life ${ }^{14,22-23}$.

Therefore, the diverse anomalies present in this patient involved a negative impact on his quality of life. The dental defects caused important esthetic changes in dentition causing disturbances of a psychological nature. The patient was shown to be dissatisfied and ashamed in the company of his social group. According to the mother's report, after treatment and consequent evolution of the health and oral esthetic conditions, the child presented

\section{REFERENCES}

1. Bezerra PKM, Calvacanti AL. Características e distribuição das maloclusões em pré-escolares. Rev Ciên Méd Biol. 2006;5(2):117-23.

2. Zanetti GA, Machado MAAM, Souza SMB, Balarotti E, Delgado FL. Características da dentadura mista e tipos de padrões faciais em crianças brasileiras. Semin, Cienc Biol Saude. 2003;24():6776. doi: 10.5433/1679-0367.2003v24n1 p67.

3. Fernandes KP, Amaral MAT, Monico MA. Ocorrência de maloclusão e necessidade de tratamento ortodôntico na dentição decídua. RGO - Rev Gaúcha Odontol. 2007;55(3):223-7. a significant improvement in self-esteem, with a notable reflection on his behavior and social life.

\section{CONCLUSION}

Integration between the dental specialties in the treatment of this patient obtained significant results with regard to the correction of occlusion and esthetic appearance of the teeth, rehabilitating the stomatognathic system, thereby generating an improvement in the patient's self-esteem and social relationships, observed during the course of the follow-up appointments and reports of the child's mother.

In spite of the limitations of interceptive orthodontic treatment in this highly complex case, the results were most satisfactory, and could be more widely disseminated in the public service of the country, thereby benefiting a large portion of the population.

\section{Collaborators}

RA SOUZA participated in the selection of the case, orthodontic study and planning, insertion of the removable orthodontic appliance, follow-up of maintenance treatments and their conclusion, and writing the article. AC CARVALHO was responsible for the oral hygiene, performed maintenance of the removable orthodontic appliance and restorations required, supervised by the professors, and writing the article. LP BARRETTO participated in writing the article, and in orthodontic attendance of the patient. FXPC SIMÕES was responsible for following up the esthetic restorations performed in the patient, and for the pediatric dentistry approach during the entire period of treatment, and writing the article.

4. Guedes-Pinto AC. Pediatric Dentistry $6^{\text {a }}$ ed. São Paulo: Editora Koogan; 1979.

5. Pinheiro CC, Tostes MA, Pinheiro AR. Prevalência de anomalia dentária de número em pacientes submetidos a tratamento ortodôntico. Pesq Bras Odontoped Clin Integr. 2008;(1):47-50.

6. Coutinho TCL, Tostes MA, Santos MEO, Bastos VAS. Anomalias dentárias em crianças: um estudo radiográfico. Rev Odontol Univ São Paulo. 1998;12(1):51-5.

7. Paixão RF, Fuziy A. Uma abordagem ortodôntica das perdas dentais precoce In: $15^{\circ}$ Conclave Odontológico Internacional de Campinas; 2003. Campinas: Associação dos CirurgiõesDentistas de Campinas; 2003. Anais; 2003. p. 104. 
8. Mendes ACS, Costa AA, Nemr K. O papel da Fonoaudiologia na Ortodontia e na Odontopediatria: avaliação do conhecimento dos Odontólogos especialistas. Rev CEFAC. 2005;7(1):60-7.

9. Grieco FAD. Prevalência de agenesia dentária em pacientes ortodônticos da cidade de São Paulo. RPG Rev Pós Grad. 2007;13(4):312-7

10. Pinheiro CC, Tostes MA, Pinheiro AR. Prevalência de anomalia dentária de número em pacientes submetidos a tratamento ortodôntico. Pesq Bras Odontoped Clin Integr. 2008;8(1):47-50.

11. Reis LFG, Giovanini A, Namba EL, Silva ELFM, Garcia MA. Dentes supranumerários retidos interferindo no tratamento ortodôntico. Rev Sul-bras Odontol. 2006;3(2):20-5

12. Santos SH. Dilaceração radicular, tratamento ortodôntico e estético: relato de um caso clínico. SOTAU Rev Virtual Odontol. 2007;1:17-22.

13. Melo REVA. Traumatismo dentoalveolar. Int J Dent. 2003;2(2):266-72.

14. Bendo CB, Scarpelli AC, Novais Junior JB, Vale MPP, Paiva SM, Pordeus IA. Hipoplasia de esmalte em incisivos permanentes: um acompanhamento de 6 meses. RGO - Rev Gaúcha Odontol. 2007;55(1):107-12.

15. Ribas AO, Czlusniak GD. Anomalias do esmalte dental: etiologia, diagnóstico e tratamento. Publ UEPG Ci Biol Saúde. 2004;10(1):23-36

16. Magnusson TE. Prevalence of hypodontia and malformations of permanent teeth in Iceland. Community Dent Oral Epidemiol. 1977;5(4):173-8.
17. Davis PJ. Hypodontia and hyperdontia of permanent teeth in Hong Kong schoolchildren. Community Dent Oral Epidemiol. 1987;15():218-20. doi: 10.1111/j.1600-0528.1987.tb00524.x

18. Stritzel F, Symons AL, Gage JP. Agenesis of the second premolar in males and females. Distribution, number and sites affected. J Clin Pediatr Dent. 1990;15(1):39-41. doi: 10.1111/j.16000528.1987.tb00524.x.

19. Martins PP. Apinhamento ântero-superior: revisão e análise crítica da literatura. Rev Dental Press Ortodon Ortop Facial. 2007:12(2):105-14. doi: 10.1590/S1415-54192007000200015.

20. Brasil. Ministério da Saúde. Projeto SB Brasil 2003. Condições de saúde bucal da população brasileira 2002-2003: resultados principais. Brasília: Ministério da Saúde; 2004.

21. Almeida MEC, Vedovello Filho M, Vedovello SAS, Lucatto A, Torrezan AT. Prevalência de má oclusão em escolares da rede estadual do município de Manaus, AM - Brasil. RGO - Rev Gaúcha Odontol. 2007;55(4):389-94.

22. Alencar CRB, Bezerra PKM, Calvacanti AL. Perda precoce de dentes decíduos: etiologia, epidemiologia e conseqüências ortodônticas. Publ UEPG Ci Biol Saúde. 2007;13(1/2):29-37.

23. Young AA, Coser RM, Flório FM, Vedovello Filho M. Diagnóstico e tratamento precoce da má-oclusão. RGO - Rev Gaúcha Odontol. 2004;52(5):347-51.

Received on: 1/3/2010 Final version resubmitted on: 25/7/2012 Approved on: 9/9/2012 